\title{
APPLICATION OF INQUIRY-BASED LEARNING MODELS TO IMPROVE STUDENT LEARNING OUTCOMES
}

\author{
Mazdawati \\ SMAN 1 Singkep Singkep Kepulawan Riau, Indonesia \\ Email: mazdawati22047@ gmail.com
}

\begin{abstract}
Abstrak
Penelitian Tindakan Kelas (PTK) yang berjudul "Penerapan Model Pembelajaran Berbasis Inquiri untuk Meningkatkan Hasil Belajar Siswa Kelas XII MIPA SMA Negeri 1 Singkep Tahun Pelajaran 2019/2020" merupakan salah satu usaha untuk meningkatkan mutu pendidikan khususnya peningkatan nilai peserta didik dalam memahami Unsur Periode 3 dan Unsur Transisi Periode 4. Hal ini dilakukan karena banyaknya peserta didik bahwa masih banyak siswa di kelas tersebut yang belum mencapai KKM yang ditetapkan sekolah yaitu 72. Pada Materi terkait dengan kimia pokok bahasan Unsur Periode 3 dan Unsur Transisi Periode 4, siswa yang mencapai KKM hanya 17 siswa (63\%) dari 27 siswa (Sumber: Data Indeks Pencapaian Hasil Belajar Siswa). Penelitian ini dilaksanakan di SMA Negeri I Singkep, Kecamatan Singkep Kabupaten Lingga kelas XII MIPA 3. Penelitian dilakukan pada semester II tahun ajaran 2019/2020. Rancangan penelitian yang digunakan adalah rancangan penelitian tindakan yang alurnya sebagai berikut: membuat perencanaan tindakan, melaksanakan tindakan dalam pembelajaran, mengadakan pengamatan terhadap pelaksanaan tindakan, dan merefleksi pelaksanaan tindakan. Hasil refleksi tersebut digunakan untuk mengambil keputusan untuk siklus selanjutnya. Data (pengamatan), dan penelitian berupa dokumentasi perencanaan, hasil observasi hasil menulis. Instrumen pengumpul data utama adalah peneliti, sedangkan instrumen pununjangnya adalah RPP, Lembar observasi, dokumentasi, dan analisis hasil evaluasi Hasil penelitian menunjukkan bahwa meningkatkan hasil belajar pada materi Unsur Periode 3 dan Unsur Transisi Periode 4, hal ini ditunjukkan adanya peningkatan yang mencapai KKM siklus I 62,96\% meningkat menjadi $78,57 \%$ pada siklus II.
\end{abstract}

Kata Kunci: model pembelajaran berbasis inquiri; hasil belajar kimia

\section{Abstract}

Classroom Action Research (CAR) entitled "Application of Inquiry-Based Learning Models to Improve Student Learning Outcomes of Class XII MIPA SMA Negeri 1 Singkep for the 2019/2020 Academic Year" is one of the efforts to improve the quality of education, especially increasing the value of students in understanding the Elements of Period 3 and Transitional Elements Period 4. This was done because of the large number of students that there were still many students in the class who had not reached the KKM set by the school, which was 72. In the material related to chemistry, the subject matter of Period 3 Elements and Period 4 Transitional Elements, students who reached the KKM only 17 students (63\%) of 27 students (Source: Student Achievement Achievement Index Data). This research

\begin{tabular}{ll}
\hline How to cite: & Mazdawati (2021) Application of Inquiry-Based Learning Models to Improve Student Learning \\
& Outcomes of Class XII Mipa Sma Negeri 1 Singkep For The 2019/2020 Academic Year, Syntax \\
& Idea, 3(7). https:// doi.org/10.36418/syntax-idea.v3i7.1308 \\
E-ISSN: & $2684-883 \mathrm{X}$ \\
Published by: & Ridwan Institute
\end{tabular}


Application of Inquiry-Based Learning Models to Improve Student Learning Outcomes of Class XII MIPA SMA Negeri 1 Singkep

was conducted at SMA Negeri I Singkep, Singkep District, Lingga Regency, class XII MIPA 3. The research was conducted in the second semester of the 2019/2020 academic year. The research design used is an action research design with the following flow: making action plans, implementing actions in learning, observing the implementation of actions, and reflecting on the implementation of actions. The results of these reflections are used to make decisions for the next cycle. Data (observations), and research in the form of planning documentation, results of writing observations. The main data collection instrument is the researcher, while the supporting instruments are lesson plans, observation sheets, documentation, and analysis of the results of the evaluation. The results of the study indicate that improving learning outcomes in the Elements of Period 3 and Transitional Elements of Period 4, this is indicated by an increase that reaches the KKM cycle I $62.96 \%$ increased to $78.57 \%$ in the second cycle.

Keywords: inquiry-based learning model; chemistry learning outcomes

\section{Pendahuluan}

Peningkatan mutu pendidikan ditentukan oleh kesiapan sumber daya manusia yang terlibat dalam proses pendidikan. Guru merupakan salah satu faktor penentu tinggi dan rendahnya mutu hasil pendidikan mempunyai posisi strategis maka setiap usaha peningkatan mutu pendidikan perlu memberikan perhatian besar kepada peningkatan guru dalam segi jumlah maupun mutunya (Nurjanah, 2010).

Sekolah merupakan lembaga pendidikan formal yang bertanggung jawab dalam mencerdaskan kehidupan bangsa. Oleh sebab itu, sekolah membutuhkan berbagai komponen penunjang terutama dalam mewujudkan proses pembelajaran yang baik dan dapat meningkatkan hasil belajar siswa. Salah satu komponen terpenting dalam mewujudkan proses pembelajaran disekolah adalah guru dan model pembelajaran. Guru merupakan ujung tombak dalam mensukseskan proses pembelajaran disekolah. Guru memiliki peran yang sangat penting dalam melaksanakan pembelajaran bersama siswa. Tercapai atau tidaknya tujuan pembelajaran di sekolah sangat tergantung pada kemampuan guru dalam memahami proses pembelajaran yang didapatkan dari penerapan model-model pembelajaran (Isjoni, 2014).

Skenario mengajar dan belajar perlu disiapkan secara matang dalam sebuah kurikulum pembelajaran yang memang dirancang berbasis internet. Mengimplementasikan pembelajaran berbasis internet bukan berarti sekedar meletakkan materi ajar pada web. Selain materi ajar, skenario pembelajaran perlu disiapkan dengan matang untuk mengundang keterlibatan peserta didik secara aktif dan konstruktif dalam proses belajar mereka (Elyas, 2018).

Mengajar merupakan tugas utama seorang pendidik (guru, dosen, tutor, instruktur, widyaiswara). Pendidik yang kreatif akan selalu menciptakan ide-ide dalam merancang sistem pembelajaran baru yang mampu membuat peserta didik dapat mencapai tujuan belajarnya dengan penuh rasa puas. Untuk memperoleh sistem pembelajaran baru tersebut diperlukan metode penelitian dan pengembangan sistem pembelajaran. Metode pengembangan sistem pembelajaran tidak jauh berbeda dengan metode pengembangan produk lainnya. Prosedur pengembangan lebih singkat karena produk yang dihasilkan 
tidak terlalu beresiko dan dampak sistem terbatas pada peserta didik yang menjadi sasaran (Mulyatiningsih, 2016).

Model pembelajaran yang digunakan dalam pembelajaran harus relevan dan mendukung tercapainya tujuan pembelajaran. Ketepatan dalam menggunakan metode atau model mengajar yang dilakukan oleh guru dapat membangkitkan motivasi dan juga minat siswa terhadap mata pelajaran yag diberikan oleh guru dan juga terhadap proses dan hasil belajar siswa. Didalam bidang pendidikan sangat banyak bidang-bidang ilmu yang terus berkembang dan salah satunya adalah Ilmu kimia. Ilmu kimia merupakan salah satu cabang Ilmu Pengetahuan Alam (IPA) yang merupakan bidang studi yang biasanya dipelajari pada tingkat SMA/MA. Pelajaran kimia pada hakekatnya adalah pelajaran yang sangat erat hubungannya dalam kehidupan sehari-hari dan telah memberikan banyak manfaat bagi manusia (Amirta, 2010).

Mata pelajaran kimia merupakan mata pelajaran yang baru diberikan secara menyeluruh di bangku SMA. Hal ini merupakan kesempatan bagi guru mata pelajaran kimia untuk memberikan kesan awal yang baik terhadap pelajaran kimia (Munandar \& Jofrishal, 2017).

Namun, pembelajaran kimia di sekolah belum begitu efektif dalam proses penerapannya di sekolah. Proses pembelajaran kimia cenderung pada pencapaian target materi menurut kurikulum dan berorientasi pada pemenuhan target ketuntasan. Konsekuensinya, proses pembelajaran tidak menekankan pada pemahaman bahan yang dipelajari. Siswa tidak membangun sendiri pengetahuan tentang konsep-konsep kimia, tetapi cenderung menghapalkan konsep-konsep tersebut tanpa tahu makna yang terkandung didalamnya. Sedangkan ilmu kimia dibangun melalui pengembanganpengembangan ketrampilan proses sains. Ketrampilan-ketrampilan proses sains harus ditumbuhkan dalam diri siswa SMA sesuai dengan taraf perkembangan pemikirannya (Musfah, 2018).

Berdasarkan data yang diperoleh penulis sebagai guru kelas XII MIPA Tahun Pelajaran 2019/2020, diperoleh informasi bahwa masih banyak siswa di kelas tersebut yang belum mencapai KKM yang ditetapkan sekolah yaitu 72. Pada Materi terkait dengan kimia pokok bahasan Unsur Periode 3 dan Unsur Transisi Periode 4, siswa yang mencapai KKM hanya 17 siswa (63\%) dari 27 siswa (Sumber: Data Indeks Pencapaian Hasil Belajar Siswa). Dari hasil observasi peneliti di kelas XII MIPA, masalah yang timbul di dalam pembelajaran adalah kurangnya partisipasi siswa di dalam proses pembelajaran. Jika guru mengajukan pertanyaan, hanya beberapa siswa saja yang menanggapi. Jika guru membentuk kelompok belajar, dalam pelaksanaannya hanya siswa tertentu saja yang terlibat aktif sedangkan siswa lain pasif. Oleh karena itu, perlu adanya pembelajaran yang efektif melalui penerapan Model-model pembelajaran salah satunya Penerapan Model Pembelajaran Berbasis Inquiri (Kencana, 2021).

Penerapan Model Pembelajaran Berbasis Inquiri mempunyai prinsip yang sama dengan inkuiri dan problem solving. Model Pembelajaran Berbasis Inquiri lebih menekankan pada konsep atau prinsip yang sebelumnya tidak diketahui atau belum ditemukan. Masalah yang dihadapi oleh siswa adalah proses dari perekayasaan yang dilakukan oleh guru tersebut. Materi yang akan disampaikan, tidak disampaikan dalam 
bentuk final akan tetapi siswa di dorong untuk mengidentifikasi apa yang ingin diketahui dan dilanjutkan mencari informasi sendiri. Strategi pembelajaran yang kurang melibatkan siswa akan menurunkan minat belajar siswa, sehingga motivasi belajarpun akan menurun dan pada akhimya prestasi belajarpun tidak akan didapatkan hasil optimal. Berdasarkan pada kenyataan tersebut intinya bahwa strategi belajar yang digunakan oleh guru sangat berpengaruh terhadap motivasi belajar peserta didik, dan yang lebih penting lagi berpengaruh terhadap keberhasilan peserta didik dalam belajar (Zubaidah \& UM, 2017).

Berdasarkan fenomena yang ada, penulis akan melakukan penelitian tindakan kelas (action research) dengan tujuan untuk mengetahui dan mendeskripsikan bahwa dengan Model Pembelajaran Berbasis Inquiri oleh guru dalam proses pembelajaran, diharapkan mampu meningkatkan prestasi belajar siswa. Penelitian ini akan mendeskripsikan suatu upaya meningkatkan hasil belajar kimia siswa kelas XII MIPA SMA Negeri 1 Singkep tahun pelajaran 2019/2020 dengan menerapkan Model Pembelajaran Berbasis Inquiri pada pokok bahasan Unsur Periode 3 dan Unsur Transisi Periode 4. Apakah dengan menerapkan Model Pembelajaran Berbasis Inquiri pada siswa kelas XII MIPA SMA Negeri 1 Singkep Tahun Pelajaran 2019/2020 dapat meningkatkan hasil belajar kimia pada pokok bahasan kimia Asam dan Basa pada Tahun Pelajaran 2019/2020 (Yaumi, 2016).

Sasaran tindakan pada penelitian ini adalah Perilaku Belajar siswa kelas XII MIPA SMA Negeri 1 Singkep Tahun Pelajaran 2019/2020 yang berjumlah 28 orang dalam pembelajaran yang menerapkan Model Pembelajaran Berbasis Inquiri dan hasil belajarnya. Adapun Tujuan utama dalam Penelitian ini adalah untuk menghasilkan desain pembelajaran yang dapat dimanfaatkan untuk meningkatkan hasil belajar dan motivasi belajar siswa. Berdasarkan tujuan utama dalam penelitian ini maka hasil penelitian tindakan kelas ini diharapkan berguna baik secara teoritis maupun secara praktis. Dengan kata lain kegunaan teoritis berarti hasil penelitian tindakan kelas ini memberikan kontribusi secara teori bagi pengembangan ilmu pengetahuan yang berkaitan dengan penelitian ini dan secara praktis mengetahui terkait Penerapan Model Pembelajaran Berbasis Inquiri Untuk Meningkatkan Hasil Belajar Kimia Siswa Kelas XII MIPA SMA Negeri 1 Singkep Tahun Pelajaran 2019/2020.

\section{Metode Penelitian}

Penelitian ini dilaksanakan di kelas XII MIPA SMA Negeri 1 Singkep tahun pelajaran 2019/2020. Pelaksanaan penelitian ini dimulai dari bulan Januari sampai dengan bulan Februari 2020. Subjek penelitian adalah siswa kelas XII MIPA SMA Negeri 1 Singkep Tahun Pelajaran 2019/2020 yang berjumlah 28 orang siswa. Adapun sasaran dari penelitian ini adalah untuk mengetahui perilaku siswa dalam penerapan menggunakan Model Pembelajaran Berbasis Inquiri terhadap hasil belajar siswa. Prosedur penelitian terdiri dari 4 tahap, yakni perencanaan, melakukan tindakan, observasi dan evaluasi. Refleksi pada setiap siklus akan berulang kembali pada siklussiklus berikutnya. Aspek yang diamati dalam setiap siklusnya adalah perilaku atau aktivitas siswa pada saat pemberian pembelajaran kimia terkait materi tentang kimia 
pokok bahasan Unsur Periode 3 dan Unsur Transisi Periode 4 dengan penerapan Model Pembelajaran Berbasis Inquiri. Dengan mengamati perubahan perubahan perilaku siswa, peneliti dapat mengetahui tingkat kemajuan belajar siswa yang akan bepengaruh terhadap hasil belajarnya.Penelitian tindakan kelas ini terdiri dari 2 siklus, siklus I terdiri dari 2 kali pertemuan dan siklus kedua terdiri dari 2 pertemuan, satu pertemuan 90 menit (Sukrawan \& Komaro, 2011).

Sumber data berupa observasi lansung pada saat pelaksanaan pembelajaran, data hasil angket motivasi, angket akhir siklus 1 dan 2, data hasil evaluasi. Pengumpulan data melalui pemberian angket motivasi prasiklus, angket akhir siklus 1 dan 2 serta evaluasi belajar akhir siklus 1 dan 2 (Nurjanah, 2010).

\section{Hasil dan Pembahasan}

\section{A. Hasil Penelitian}

\section{Siklus 1}

\section{a. Tahap Perencanaan}

Pada tahap ini peneliti mempersiapkan perangkat pembelajaran yang terdiri dari rencana pelajaran 1 , LKS 1 , soal tes formatif 1 , dan alat-alat pengajaran yang mendukung.

\section{b. Tahap Kegiatan dan Pelaksanaan}

Pelaksanaan kegiatan belajar mengajar untuk siklus 1 dilaksanakan pada tanggal 12 dan 19 Januari 2020 di Kelas XII IPA dengan jumlah siswa 28 siswa. Dalam hal ini peneliti bertindak sebagai guru. Adapun proses belajar mengajar mengacu pada rencana pelajaran yang telah dipersiapkan. Pengamatan (observasi) dilaksanakan bersamaan dengan pelaksaaan belajar mengajar.

Pada akhir proses belajar mengajar siswa diberi tes formatif I dengan tujuan untuk mengetahui tingkat keberhasilan siswa dalam proses belajar mengajar yang telah dilakukan. Adapun data hasil penelitian pada siklus 1 adalah sebagai berikut:

Tabel 1

Pengelolan Pembelajaran Pada Siklus 1

\begin{tabular}{|c|c|c|c|c|}
\hline \multirow{2}{*}{ No } & \multirow{2}{*}{ Aspek yang diamati } & \multicolumn{2}{|c|}{ Penilaian } & \multirow{2}{*}{$\begin{array}{c}\text { Rata- } \\
\text { rata }\end{array}$} \\
\hline & & P1 & $\mathrm{P} 2$ & \\
\hline \multirow[t]{10}{*}{$\mathbf{I}$} & Pengamatan KBM & & & \\
\hline & A. Pendahuluan & & & \\
\hline & 1. Memotivasi siswa & 3 & 2 & 2,5 \\
\hline & 2. Menyampaikan tujuan pembelajaran & 1 & 2 & 1,5 \\
\hline & B. Kegiatan Inti & & & \\
\hline & 1. Mendiskusikan langkah-langkah kegiatan & 3 & 3 & 3 \\
\hline & bersama siswa & 3 & 3 & 3 \\
\hline & 2. Membimbing siswa melakukan kegiatan & & & \\
\hline & $\begin{array}{l}\text { 3. Membimbing siswa mendiskusikan hasil } \\
\text { kegiatan dalam kelompok }\end{array}$ & 3 & 3 & 3 \\
\hline & $\begin{array}{l}\text { 4. Memberikan kesempatan pada siswa untuk } \\
\text { mempresentasikan hasil kegiatan belajar }\end{array}$ & 3 & 3 & 3 \\
\hline
\end{tabular}




\begin{tabular}{lllll}
\hline & $\begin{array}{l}\text { mengajar } \\
\text { 5. Membimbing siswa merumuskan } \\
\text { kesimpulan/menemukan konsep }\end{array}$ & 3 & 3 & $\mathbf{3}$ \\
& & & \\
\cline { 2 - 5 } & C. Penutup & & & \\
& 1. Membimbing siswa membuat rangkuman & 3 & 3 & $\mathbf{3}$ \\
& 2. Memberikan evaluasi & 3 & 3 & $\mathbf{3}$ \\
\hline II $\quad$ Pengelolaan Waktu & 2 & 2 & $\mathbf{2}$ \\
\hline III & Antusiasme Kelas & & & \\
& 1. Siswa Antusias & 3 & 3 & $\mathbf{3}$ \\
& 2. Guru Antusias & 3 & 3 & $\mathbf{3}$ \\
\hline & Jumlah & $\mathbf{3 1}$ & $\mathbf{3 1}$ & $\mathbf{3 1}$ \\
\hline
\end{tabular}

Keterangan: Nilai : Kriteria

1.: Tidak Baik

2.: Kurang Baik

3.: Cukup Baik

4.: Baik

Berdasarkan tabel 1 aspek-aspek yang mendapatkan kriteria kurang baik adalah memotivasi siswa, menyampaikan tujuan pembelajaran, pengelolaan waktu. Ketiga aspek yang mendapat penilaian kurang baik di atas, merupakan suatu kelemahan yang terjadi pada siklus 1. Dan akan dijadikan bahan kajian untuk refleksi dan revisi yang akan dilakukan pada siklus 2 pada tabel berikut :

Tabel 2

Aktivitas Guru Dan Siswa Pada Siklus 1

\begin{tabular}{clc}
\hline No & \multicolumn{1}{c}{ Aktivitas Guru yang diamati } & Persentase \\
\hline $\mathbf{1}$ & Menyampaikan tujuan & $\mathbf{1 0 . 0 0}$ \\
$\mathbf{2}$ & Memotivasi siswa/merumuskan masalah & $\mathbf{1 0 . 0 0}$ \\
$\mathbf{3}$ & Mengkaitkan dengan pelajaran berikutnya & $\mathbf{6 . 6 7}$ \\
$\mathbf{4}$ & Menyampaikan materi/langkah-langkah/strategi & $\mathbf{8 . 3 3}$ \\
$\mathbf{5}$ & Menjelaskan materi yang sulit & $\mathbf{1 3 . 3 3}$ \\
$\mathbf{6}$ & Membimbing dan mengamati siswa dalam & $\mathbf{1 5 . 0 0}$ \\
& menemukan konsep & $\mathbf{1 0 . 0 0}$ \\
$\mathbf{7}$ & Meminta siswa menyajikan dan mendiskusikan hasil & \\
$\mathbf{8}$ & kegiatan & $\mathbf{1 8 . 3 3}$ \\
$\mathbf{9}$ & Memberikan umpan balik & $\mathbf{8 . 3 3}$ \\
\hline & Membimbing siswa merangkum pelajaran & Persentase \\
\hline No & $\quad$ Aktivitas Siswa yang diamati & 19.16 \\
1 & Mendengarkan/memperhatikan penjelasan guru & 11.86 \\
2 & Membaca buku siswa & 18.13 \\
3 & Bekerja dengan sesama anggota kelompok & 14.38 \\
4 & Diskusi antar siswa/antara siswa dengan guru & 5.83 \\
5 & Menyajikan hasil pembelajaran & 5.63 \\
6 & Mengajukan/menanggapi pertanyaan/ide & 9.17 \\
7 & Menulis yang relevan dengan KBM & 6.86 \\
8 & Merangkum pembelajaran & 8.96 \\
9 & Mengerjakan tes evaluasi &
\end{tabular}


Berdasarkan tabel 2 tampak bahwa aktivitas guru yang paling dominan pada siklus 1 adalah memberi umpan balik dan membimbing dan mengamati siswa dalam menemukan konsep yaitu masing-masing 18,33 dan 15,00\%. Aktivitas lain yang persentasenya cukup besar adalah menjelaskan materi yang sulit yaitu 13,33\%. Sedangkan aktivitas siswa yang paling dominan adalah mengerjakan/memperhatikan penjelasan guru yaitu 19,16\%. Aktivitas lain yang persentasenya cukup besar adalah bekerja dengan sesama anggota kelompok, diskusi antar siswa/antara siswa dengan guru, dan membaca buku yaitu masingmasing $18,13 \%, 14,38$ dan $11,86 \%$.

Pada siklus 1, secara garis besar kegiatan belajar mengajar dengan Model Pembelajaran Berbasis Inquiri sudah dilaksanakan dengan baik, walaupun peran guru masih cukup dominan untuk memberikan penjelasan dan arahan karena model tersebut masih dirasakan baru oleh siswa.

Berikutnya adalah rekapitulasi hasil tes formatif siswa seperti terlihat pada tabel berikut:

Tabel 3

Rekapitulasi Hasil Tes Siklus 1

\begin{tabular}{clc}
\hline No & \multicolumn{1}{c}{ Uraian } & Hasil Siklus I \\
\hline & Jumlah siswa yang tuntas & 17 \\
& Jumlah siswa belum tuntas & 11 \\
& Nilai rata-rata tes formatif & 68 \\
& Persentase ketuntasan belajar & $62,96 \%$ \\
\hline
\end{tabular}

Dari tabel 3 dapat dijelaskan bahwa dengan menerapkan Model Pembelajaran Berbasis Inquiri diperoleh nilai rata-rata prestasi belajar siswa adalah 68 dan ketuntasan belajar mencapai 62,96\% atau ada 11 siswa dari 28 siswa sudah tuntas belajar. Hasil tersebut menunjukkan bahwa pada siklus pertama secara klasikal siswa belum tuntas belajar, karena siswa yang memperoleh nilai $\geq 75$ hanya sebesar 62,96\% lebih kecil dari persentase ketuntasan yang dikehendaki yaitu sebesar 70\%. Hal ini disebabkan karena siswa masih merasa baru dan belum mengerti apa yang dimaksudkan dan digunakan guru dengan menerapkan Model Pembelajaran Berbasis Inquiri.

2. Siklus 2

\section{a. Tahap perencanaan}

Pada tahap ini peneliti mempersiapkan perangkat pembelajaran yang terdiri dari rencana pelajaran 2, LKS 2 , soal tes formatif II, dan alat-alat pengajaran yang mendukung.

\section{b. Tahap kegiatan dan pelaksanaan}

Pelaksanaan kegiatan belajar mengajar untuk siklus 2 dilaksanakan pada tanggal 23 dan 29 Januari 2020 di Kelas XII MIPA dengan jumlah siswa 28 siswa. Dalam hal ini peneliti bertindak sebagai guru. Adapun proses belajar mengajar mengacu pada rencana pelajaran dengan memperhatikan revisi pada 
siklus 1, sehingga kesalahan atau kekurangan pada siklus 1 tidak terulang lagi pada siklus 2. Pengamatan (observasi) dilaksanakan bersamaan dengan pelaksanaan belajar mengajar.

Pada akhir proses belajar mengajar siswa diberi tes formatif II dengan tujuan untuk mengetahui tingkat keberhasilan siswa selama proses belajar mengajar yang telah dilakukan. Instrumen yang digunakan adalah tes formatif II. Adapun data hasil penelitian pada siklus 2 adalah sebagai berikut:

Tabel 4

Pengelolaan Pembelajaran Pada Siklus 2

\begin{tabular}{|c|c|c|c|c|}
\hline \multirow[t]{2}{*}{ No } & \multirow[t]{2}{*}{ Aspek yang diamati } & \multicolumn{2}{|c|}{ Penilaian } & \multirow{2}{*}{$\begin{array}{c}\text { Rata- } \\
\text { rata }\end{array}$} \\
\hline & & $\mathrm{P} 1$ & $\mathrm{P} 2$ & \\
\hline \multirow[t]{14}{*}{$\mathbf{I}$} & Pengamatan KBM & & & \\
\hline & A. Pendahuluan & & & \\
\hline & 1. Memotivasi siswa & 3 & 3 & 3 \\
\hline & 2. Menyampaikan tujuan pembelajaran & 3 & 3 & 3 \\
\hline & B. Kegiatan Inti & & & \\
\hline & $\begin{array}{l}\text { 1. Mendiskusikan langkah-langkah kegiatan } \\
\text { bersama siswa }\end{array}$ & 3 & 3 & 3 \\
\hline & 2. Membimbing siswa melakukan kegiatan & 4 & 4 & 4 \\
\hline & $\begin{array}{l}\text { 3. Membimbing siswa mendiskusikan hasil } \\
\text { kegiatan dalam kelompok }\end{array}$ & 4 & 4 & 4 \\
\hline & $\begin{array}{l}\text { 4. Memberikan kesempatan pada siswa untuk } \\
\text { mempresentasikan hasil kegiatan belajar }\end{array}$ & 4 & 4 & 4 \\
\hline & mengajar & 3 & 3 & 3 \\
\hline & $\begin{array}{l}\text { 5. Membimbing siswa merumuskan } \\
\text { kesimpulan/menemukan konsep }\end{array}$ & & & \\
\hline & C. Penutup & & & \\
\hline & 1. Membimbing siswa membuat rangkuman & 3 & 4 & 3,5 \\
\hline & 2. Memberikan evaluasi & 4 & 4 & 4 \\
\hline II & Pengelolaan Waktu & 3 & 3 & 2 \\
\hline \multirow[t]{4}{*}{ III } & Antusiasme Kelas & & & \\
\hline & 1. Siswa Antusias & 4 & 3 & 3,5 \\
\hline & 2. Guru Antusias & 4 & 4 & 4 \\
\hline & Jumlah & 42 & 42 & 42 \\
\hline
\end{tabular}

Keterangan: Nilai : Kriteria

1 : Tidak Baik

2 : Kurang Baik

3 : Cukup Baik

4 : Baik

Dari tabel 4, tampak aspek-aspek yang diamati pada kegiatan belajar mengajar (siklus 2) yang dilaksanakan oleh guru dengan menerapkan strategi pembelajaran peningkatan kemampuan berpikir mendapatkan penilaian yang cukup baik dari pengamat. Maksudnya dari seluruh penilaian tidak terdapat nilai kurang. Namum demikian penilaian tersebut belum merupakan hasil yang optimal, untuk itu ada beberapa aspek yang perlu mendapatkan perhatian untuk 
penyempurnaan penerapan pembelajaran selanjutnya. Aspek-aspek tersebut adalah memotivasi siswa, membimbing siswa merumuskan kesimpulan/ menemukan konsep, dan pengelolaan waktu.

Dengan penyempurnaan aspek-aspek di atas dalam penerapan strategi pembelajaran peningkatan kemampuan berpikir diharapkan siswa dapat menyimpulkan apa yang telah mereka pelajari dan mengemukakan pendapatnya sehingga mereka akan lebih memahami tentang apa yang telah mereka lakukan. Berikut disajikan hasil observasi aktivitas guru dan siswa:

\section{Tabel 5}

Aktivitas Guru Dan Siswa Pada Siklus 2

\begin{tabular}{clc}
\hline No & \multicolumn{1}{c}{ Aktivitas Guru yang diamati } & $\begin{array}{c}\text { Persentas } \\
\text { e }\end{array}$ \\
\hline 1 & Menyampaikan tujuan & 3,33 \\
2 & Memotivasi siswa/merumuskan masalah & 10,00 \\
3 & Mengkaitkan dengan pelajaran berikutnya & 6,67 \\
4 & Menyampaikan materi/langkah-langkah/strategi & 11,67 \\
5 & Menjelaskan materi yang sulit & 18,33 \\
6 & Membimbing dan mengamati siswa dalam & 15,00 \\
& menentukan konsep & \\
7 & Meminta siswa menyajikan dan mendiskusikan hasil & 8,33 \\
& kegiatan & \\
8 & Memberikan umpan balik & 18,33 \\
9 & Membimbing siswa merangkum pelajaran & 8,33 \\
\hline No & \multicolumn{2}{c}{ Aktivitas Siswa yang diamati } \\
& & Persentas \\
\hline 1 & Mendengarkan/memperhatikan penjelasan guru & 18,12 \\
2 & Membaca buku siswa & 15,63 \\
3 & Bekerja dengan sesama anggota kelompok & 20,21 \\
4 & Diskusi antar siswa/antara siswa dengan guru & 14,76 \\
5 & Menyajikanhasil pembelajaran & 3,33 \\
6 & Mengajukan/menanggapi pertanyaan/ide & 6,67 \\
7 & Menulis yang relevan dengan KBM & 7,91 \\
8 & Merangkum pembelajaran & 6,67 \\
9 & Mengerjakan tes evaluasi/latihan & 6,67 \\
\hline
\end{tabular}

Berdasarkan tabel 5 tampak bahwa aktivitas guru yang paling dominan pada siklus 2 adalah menjelaskan materi yang sulit dan memberikan umpan balik yaitu masing-masing 18,33\%, kemudian menyampaikan langkah-langkah strategis yaitu $11,67 \%$. Sedangkan untuk aktivitas siswa yang paling dominan pada siklus 2 adalah Bekerja dengan sesama anggota kelompok, mendengarkan penjelasan guru, membaca buku, dan diskusi antar siswa/antara siswa dengan guru yaitu 20,21\%, 18,12\%, 15,63\% dan 14,76\%. Berikutnya adalah rekapitulasi hasil tes formatif siswa terlihat pada tabel berikut: 
Tabel 6

Rekapitulasi Hasil Tes Siklus 2

\begin{tabular}{ccc}
\hline No & Uraian & Hasil Siklus II \\
\hline 1 & Jumlah siswa yang tuntas & 22 \\
2 & Jumlah siswa belum tuntas & 6 \\
3 & Nilai rata-rata tes formatif & 80,78 \\
4 & Persentase ketuntasan belajar & 78,57 \\
\hline
\end{tabular}

Dari tabel 6 diperoleh nilai rata-rata prestasi belajar siswa adalah 80,78 dan ketuntasan belajar mencapai 78,57\% atau ada 6 siswa dari 28 siswa sudah tuntas belajar. Hasil ini menunjukkan bahwa pada siklus 2 ini ketuntasan belajar secara klasikal telah mengalami peningkatan sedikit lebih baik dari siklus 1. Adanya peningkatan hasil belajar siswa ini karena setelah guru menginformasikan bahwa setiap akhir pelajaran akan selalu diadakan tes sehingga pada pertemuan berikutnya siswa lebih termotivasi untuk belajar. Selain itu siswa juga sudah mulai mengerti apa yang dimaksudkan dan diinginkan guru dengan menerapkan metode Model pembelajaran penemuan Berbasis Inquiri.

Tabel 7

Daftar Distribusi Frekwensi hasil belajar

\begin{tabular}{ccc}
\hline Uraian & Siklus 1 & Siklus 2 \\
\hline Siswa yang Tuntas & 17 & 22 \\
Siswa yang tidakTuntas & 11 & 6 \\
Nilai rata-rata tes formatif & 68 & 80,78 \\
Persentase ketuntasan belajar & $62,96 \%$ & 78,57 \\
\hline
\end{tabular}

\section{c. Refleksi}

Pada tahap ini akah dikaji apa yang telah terlaksana dengan baik maupun yang masih kurang baik dalam proses belajar mengajar dengan penerapan Model Pembelajaran Berbasis Inquiri. Dari data-data yang telah diperoleh dapat diuraikan sebagai berikut:

1. Selama proses belajar mengajar guru telah melaksanakan semua pembelajaran dengan baik. Meskipun ada beberapa aspek yang belum sempurna, tetapi persentase pelaksanaannya untuk masing-masing aspek cukup besar.

2. Berdasarkan data hasil pengamatan diketahui bahwa siswa aktif selama proses belajar berlangsung.

3. Kekurangan pada siklus-siklus sebelumnya sudah mengalami perbaikan dan peningkatan sehingga menjadi lebih baik.

4. Hasil belajar siswa belum mencapai ketuntasan seperti yang diharapkan tetapi ada peningkatan hasil belajar. 


\section{d. Revisi Pelaksanaan}

Pada siklus 1 dan 2 guru telah menerapkan Model pembelajaran Berbasis Inquiri dengan baik dan dilihat dari aktivitas siswa serta hasil belajar siswa pelaksanaan proses belajar mengajar sudah berjalan dengan baik. Maka tidak diperlukan revisi terlalu banyak, tetapi yang perlu diperhatikan untuk tindakan selanjutnya adalah memaksimalkan dan mempertahankan apa yang telah ada dengan tujuan agar pada pelaksanaan proses belajar mengajar selanjutnya penerapan Model pembelajaran Berbasis Inquiri dapat meningkatkan proses belajar mengajar sehingga tujuan pembelajaran dapat tercapai.

\section{B. Pembahasan}

Berdasarkan hasil penelitian yang telah dipapar sebelumnya, maka telah diketahui hasil dari penelitian ini. Selanjutnya, agar lebih memperjelas hasil dari pada penelitian ini, sebagai berikut:

1. Ketuntasan Hasil belajar Siswa, melalui hasil peneilitian ini menunjukkan bahwa Model Pembelajaran Berbasis Inquiri memiliki dampak positif dalam meningkatkan prestasi belajar siswa. Hal ini dapat dilihat dari semakin mantapnya pemahaman siswa terhadap materi yang disampaikan guru (ketuntasan belajar meningkat dari siklus 1 dan 2) yaitu masing-masing 63,89\%, dan $75 \%$ (Kistian, 2019).

2. Kemampuan Guru dalam Mengelola Pembelajaran , berdasarkan analisis data, diperoleh aktivitas siswa dalam proses pembelajaran Model Pembelajaran Berbasis Inquiri dalam setiap siklus mengalami peningkatan. Hal ini berdampak positif terhadap prestasi belajar siswa yaitu dapat ditunjukkan dengan meningkatnya nilai rata-rata siswa pada setiap siklus yang terus mengalami peningkatan (Triani et al., 2018).

3. Aktivitas Guru dan Siswa Dalam Pembelajaran, berdasarkan analisis data, diperoleh aktivitas siswa dalam proses pembelajaran kimia pada pokok bahasan Unsur Periode 3 dan Unsur Transisi Periode 4 yang paling dominan adalah bekerja dengan menggunakan alat/media, mendengarkan/ memperhatikan penjelasan guru, dan diskusi antar siswa/antara siswa dengan guru. Jadi dapat dikatakan bahwa aktivitas siswa dapat dikategorikan aktif. Sedangkan untuk aktivitas guru selama pembelajaran telah melaksanakan langah-langkah pembelajaran Model Pembelajaran Berbasis Inquiri dengan baik. Hal ini terlihat dari aktivitas guru yang muncul di antaranya aktivitas membimbing dan mengamati siswa dalam mengerjakan kegiatan LKS / menemukan konsep, menjelaskan/melatih menggunakan alat, memberi umpan balik/evaluasi/tanya jawab dimana prosentase untuk aktivitas di atas cukup besar (Asmara, 2017). 


\section{Kesimpulan}

Berdasarkan hasil penelitian ini, dapat dirumuskan beberapa kesimpulan, diantaranya: Pertama, Pengembangan Model pembelajaran berbasis inquiri Sekolah Menengah Atas dapat meningkatkan motivasi Siswa Kelas XII MIPA SMA Negeri 1 Singkep. Sebagai buktinya bahwa pengajaran yang dilakukan mengalami peningkatan yang signifikan dari hasil belajar yang diperoleh. Bahwa antara siklus 1 dan 2, motivasi belajar siswa dengan model pembelajaran penemuan terbimbing menunjukkan neningkatan. Dari data tersebut menunjukkan bahwa siklus 1 dan siklus 2, motivasi belajar siswa dengan model pembelajaran inquiry menunjukkan peningkatan. Pada siklus I nilai tertinggi $9.09 \%$, tetapi pada pelaksanaan siklus II peningkatan drastis dengan nilai tertinggi sejumlah $63.7 \%$ dengan jumlah responden yang sama yaitu 11 responden. Peningkatan motivasi belajar siswa ini menunjukkan bahwa prestasi belajar dipengaruhi oleh strategi belajar yang diberikan guru. Prestasi belajar dapat baik bila motivasi belajarnya juga baik. Kedua, Inquiry salah satu komponen Contekstual Teaching and Learning (CTL). Strategi ini dapat dilakukan pada semua mata pelajaran. Ketiga, Strategi pembelajaran dengan menggunakan strategi pembelajaran inquiry dimungkinkan dapat meningkatkan motivasi belajar Siswa XII MIPA SMA Negeri 1 Singkep pada mata pelajaran Kimia. 


\section{BIBLIOGRAFI}

Amirta, Acep. (2010). Pengaruh model pembelajaran kooperatif dengan teknik talking chips terhadap hasil belajar kimia pada konsep ikatan kimia.Google Scholar

Asmara, Anjar Purba. (2017). Penilaian Hasil Belajar Siswa Dalam Pembelajaran Kimia Materi Kimia Unsur Menggunakan Mind Map Di Kelas XII IPA Semester 1 SMA Negeri 1 Wonosari. Lantanida Journal, 3(1), 34-54. Google Scholar

Elyas, Ananda Hadi. (2018). Penggunaan model pembelajaran e-learning dalam meningkatkan kualitas pembelajaran. Warta Dharmawangsa, (56). Google Scholar

Isjoni. (2014). Cooperative Learning. Bandung: Alfabeta.

Kencana, Sang Ayu Ketut Yunari Rat. (2021). Meningkatkan Prestasi Belajar Bahasa Daerah Bali Dengan Penggunaan Model Pembelajaran Two Stay Two Stray Siswa Kelas Xii MIPA. 5 Semester I SMA Negeri 4 Denpasar Tahun Pelajaran 2019/2020. WIDYALAYA: Jurnal Ilmu Pendidikan, 1(3), 306-317. Google Scholar

Kistian, Agus. (2019). Penerapan Model Pembelajaran Problem Based Learning (PBL) Dalam Meningkatkan Hasil Belajar Siswa Kelas IV SD Negeri Ujong Tanjong Kabupaten Aceh Barat. Genta Mulia: Jurnal Ilmiah Pendidikan, 10(2). Google Scholar

Mulyatiningsih, Endang. (2016). Pengembangan model pembelajaran. Diakses Dari Http://Staff. Uny. Ac. Id/Sites/Default/Files/Pengabdian/Dra-EndangMulyatiningsih-Mpd/7cpengembangan-Model-Pembelajaran. $\quad$ Pdf. $\quad$ Pada September.

Munandar, Haris, \& Jofrishal, Jofrishal. (2017). Analisis Pelaksanaan Pembelajaran Kimia di Kelas Homogen (Studi Kasus Pembelajaran Kimia di SMA Negeri 11 Banda Aceh). Lantanida Journal, 4(2), 98-110. Google Scholar

Musfah, Jejen. (2018). Manajemen pendidikan aplikasi, strategi, dan inovasi. Prenada Media. Google Scholar

Nurjanah, Danik. (2010). Penerapan Pembelajaran Kooperatif Think Pair Share untuk Meningkatkan Minat Belajar Biologi Siswa Kelas X-3 SMA Negeri 1 Mojolaban Tahun Pelajaran 2010/2011. Google Scholar

Sukrawan, Yusep, \& Komaro, Mumu. (2011). Problem Based Learning pada Mata Pelajaran Dasar Kompetensi Kejuruan Teknik Mesin. Invotec, VII, 1, 93-113. Google Scholar

Triani, Liliek, Wahyuni, Sri, Purwanti, Elly, Hudha, Atok Miftachul, Fatmawati, Diani, \& Husamah, Husamah. (2018). Pembelajaran I-CARE berbantuan praktikum: Peningkatan problem-solving skills dan hasil belajar siswa pada materi jaringan hewan. Jurnal Inovasi Pendidikan IPA, 4(2), 158-168. Google Scholar 
Application of Inquiry-Based Learning Models to Improve Student Learning Outcomes of Class XII MIPA SMA Negeri 1 Singkep

Yaumi, Muhammad. (2016). Action Research: Teori, model dan aplikasinya. Prenada Media. Google Scholar

Zubaidah, Siti, \& UM, JBFUNM. (2017). Pembelajaran kontekstual berbasis pemecahan masalah untuk mengembangkan kemampuan berpikir kritis. Makalah Disampaikan Pada Seminar Nasional Dengan Tema Inovasi Pembelajaran Berbasis Pemecahan Masalah Dalam Pembelajaran Biologi Di Universitas Muhammadiyah Makasar, Makasar, 6. Google Scholar

Copyright holder :

Adil Musty Tamzil, Kuswanti dan Mediana Urfah (2021)

First publication right :

Syntax Idea

This article is licensed under:

(c) (i) (?) 